\title{
Ratisbonneovo obraćenje posredstvom Čudotvorne medaljice
}

\author{
BORIS VULIĆ* \\ UDK: 2-184+27-312 Ratisbonn, A.M. • Izvorni znanstveni rad \\ Primljeno: 6. rujna 2017. • Prihvaćeno: 23. studenoga 2017. \\ »Ako bih vam morao ispričati sam događaj svoga obraćenja, \\ jedna bi riječ bila dosta: ime Marijino! « \\ (A. M. RATISBONNE, Conversione, 9.)
}

${ }^{*}$ Doc. dr. sc. Boris Vulić,

Katolički bogoslovni fakultet u Đakovu Sveučilišta J.J. Strossmayera u Osijeku, P. Preradovića 17, 31400 Đakovo, Hrvatska, vulic@me.com

Sažetak: Ustupci koji se čine u obraćenju doveli su do raspršenosti cjeline obraćenja te sumrak jezgre obraćenja kao radikalnog, ponekad naglog događaja u ljudskom životu zbog novosti Isusa Krista. Zbog toga su obraćenja često nestalna, površna $i$ zapostavljena. Ċlanak ima za cilj ukazati na radikalnost $i$ nužnost obraćenja predstavljajući obraćenje Židova Alphonsea Ratisbonnea na katoličanstvo, koje se dogodilo 1842. godine u Rimu. Ovo zadivljujuće preobraženje najveće je obraćenje posredstvom Čudotvorne medaljice, koje je ipak nedovoljno osvijetlieno u našem ambijentu. $U$ drugom se dijelu donose neki teološki aspekti koji su trajni sadržaji i dinamizmi svakog istinskog obraćenja. Postaje jasno da su nagla obraćenja moguća, da su ona bitno kristološki događaji koji donose plodove za život Crkve te da u njima svakako sudjeluju i 'misionari milosrda' posrednici koje Bog stavlja na put obraćenja pojedinih osoba. Prva je među njima Blažena Djevica Marija. Spomenuto se na jedinstven način sažima u pokretu »Vojska Bezgrešne «, ujedno ocrtavajući dar i zadatak svakog krštenika.

Ključne riječi: Alphonse Maria Ratisbonne, Blažena Djevica Marija, Čudotvorna medaljica, obraćenje, katoličanstvo, posredništvo.

\section{Uvod}

Obraćenje je jedna od središnjih kategorija povijesti spasenja, a time i kršćanstva, ukoliko je ono početak ostvarivanja 
Božjega plana spasenja ovdje i sada s konkretnim čovjekom koji je stvoren i spašen u Isusu Kristu (usp. Kol 1, 15-20). Upravo zato što je obraćenje uvelike događaj između Boga i pojedinog čovjeka, putovi su i vrste obraćenja mnogobrojni. Među njima su, u Crkvi, ali i u svijetu, posebnu kerigmatsku snagu nosila ona obraćenja koja su se dogodila naglo i potpuno, uvijek iznova potičući nova i/ili bolja obraćenja. Najpoznatiji nam je primjer obraćenja sv. Pavla, apostola naroda. Međutim, danas se takva iznenadna i radikalna obraćenja nalaze u pomrčini čovjekove pozornosti, ozbiljno lišena mogućnosti da mu otkriju ono što se njega istinski tiče. ${ }^{1}$

Duh modernog doba postao je ozbiljno zatvoren za ono što možemo nazvati pavlovskim licem obraćenja. Taj duh, čiji su mehanizmi hladna racionalnost, fragmentarnost i površnost te koji veliča ideju tolerancije izraženu u formi ravnodušnosti i relativizma, pokazuje se ozbiljno nepropusnim za onostrano, za božansko. Kao takav, duh modernog doba ostaje ili neosjetljiv ili protivan mogućnosti naglog obraćenja, označavajući takve događaje već u samom predrazumijevanju kao beznačajne, fanatične, nelogične, iracionalne i na koncu lažne. Budući da je obraćenje uvijek povezano sa situacijom, svakako da navedeno stanje nepovoljno utječe i na osobe, kao i na same okolnosti, po kojima se treba otvoriti put za nova nagla obraćenja. Stoga ćemo kao pokušaj obnove mogućnosti naglog obraćenja ovdje i sada u sljedećem koraku narativno prikazati obraćenje židova Alphonsea Ratisbonnea, koje možemo nazvati 'pavlovskim' obraćenjem 19. stoljeća i najpoznatijim čudom koje se ikad dogodilo posredstvom Čudotvorne medaljice. ${ }^{2}$ Iz te ćemo naracije u drugom poglavlju izvesti neke teološke vidove obraćenja kao takvog, koji također mogu biti zapostavljeni uslijed gubitka pozornosti spram mogućnosti istinskih obraćenja.

\footnotetext{
${ }^{1}$ O krizi vjere kao obraćenja, koja izvire iz raspršenosti pojma metanoia, ismjehivanja grijeha i kajanja te iz obraćenja k svijetu, vidi više u: J. RATZINGER, Teološki nauk o principima. Elementi fundamentalne teologije, Rijeka, 2010., 63s.

${ }^{2}$ Godine 1830. sv. Katarina Labouré doživjela je viđenje Gospe, koja je zatražila da se napravi medaljica s njezinim likom. Obećala je da će svi oni koji ju s pouzdanjem budu nosili iskusiti velike milosti. Na jednoj je strani medaljice lik Gospe koja stoji na oblaku s raširenim rukama iz kojih izlaze sunčeve zrake. Ispod je godina ukazanja, a okolo natpis: »O Marijo, bez grijeha začeta, moli za nas koji se tebi utječemo $\ll$. S druge je strane u sredini slovo M, iznad njega križ, a ispod su dva srca, od kojih je jedno okrunjeno, a drugo probodeno mačem. Sve je omeđeno krunom od 12 zvijezda. Godine 1832. pariški nadbiskup dozvoljava kovanje medaljica. Početak je to velikog širenja medaljice i pobožnosti povezane s njom. Zbog brojnih uslišanja prozvana je čudotvornom. O povijesti medaljice više u: A. BERNET, Skroviti život Katarine Labouré ili Čudesna povijest Čudotvorne medaljice, Zagreb, 2016., 167s.; http://www.vojska-bezgresne.com/cudotvorna-medaljica (25. V. 2017.). Spomenimo i to da su tridesete godine 19. stoljeća bile 'prazne' s obzirom na novu marijansku literaturu. Stvari će se početi mijenjati prvim Gospinim ukazanjem u tome stoljeću, spomenute 1830. godine, koje će potaknuti mnogobrojna obraćenja te novi val marijanske pobožnosti koji će se nadahnjivati na Marijinu bezgrešnom začeću i njezinu posredništvu. Usp. R. LAURENTIN, Breve trattato sulla Vergine Maria, Cinisello Balsamo, 2016., 124.-126.
} 


\section{Naglo i potpuno obraćenje Alphonsea Ratisbonnea}

Alphonse Tobia Ratisbonne rođen je 1. svibnja 1814. godine u Strasbourgu. ${ }^{3}$ Školovao se $\mathrm{u}$ rodnom mjestu te $\mathrm{u}$ Parizu, gdje je boravio u jednoj protestantskoj ustanovi. Rano je ostao bez roditelja. Tijekom školovanja, kako sam piše, više je rastao u raskomadanosti duše nego u stjecanju pameti, puno se više posvećivao užitcima nego znanosti. Po tome je bio jednak većini studenata, pa i onih katoličkih i protestantskih, svoga miljea čiji su prosvijetljeni duh prožimali voluntarizam i pozitivizam, materijalizam i pragmatizam. ${ }^{4}$ Završio je studij književnosti i prava te se vraća u rodno mjesto kako bi svome imućnom stricu pomogao u upravljanju bankom. Ono što će uvelike utjecati na njegov život odluka je da, prije negoli dočeka punoljetnost zaručnice i s njom stupi u brak, sam pođe na dugo turističko putovanje. Nije se odazvao pozivima da posjeti Pariz ili Španjolsku, nego odlučuje poći prema Istoku. Putovanje započinje u studenome 1841., dakle sa svojih 27 godina. Plan je bio doputovati u Napulj, potom otići na Maltu te zatim u Carigrad i dalje prema Istoku. Pohod Rimu nipošto nije bio u planu.

Iako sklon užitcima i zabavama, kroz spise koje smo proučavali, upoznajemo ga kao dobrog čovjeka nemirna duha koji drži do vjernosti i pravednosti te ima dosta prijatelja. Żivi u obilju materijalnoga, ali je spreman i pomoći potrebnim sunarodnjacima. Životna mu je filozofija liberalna, što je posve u skladu s duhom njegova vremena.

Kakav je bio njegov odnos spram Boga i katoličanstva? Taj odnos možemo podijeliti u tri, prilično jasno odvojene faze. U prvoj fazi, koja traje do njegove 11 godine, pokazuje ravnodušnost spram katoličanstva i osobne vjere koja ide ruku pod ruku $\mathrm{s}$ ateizmom i otvara prostore za mržnju prema Crkvi. Iako rođen u židovskoj obitelji, indiferentizam je bio i njegov stav spram židovstva, zbog čega ni on ni njegova obitelj nisu držali ni do najosnovnijih religijskih propisa. Ovako tvrdi: »Bijah Židov po imenu, to je sve; štoviše, nisam vjerovao ni u Boga. Nikad nisam otvorio ni jednu vjersku knjigu. $\ll^{5}$

\footnotetext{
${ }^{3}$ U sljedećem prikazu oslanjamo se na Ratisbonneov vlastiti spis o obraćenju: A. M. RATISBONNE, Conversione di un Israelita. Narazione autobiografica, Chieti, 2008. (dalje: Conversione), kao i na: A. BERNET, Skroviti život Katarine Labouré ili Čudesna povijest Čudotvorne medaljice, 244.-255.; J. SUKNER (ur.), Veliki znak 3, Zagreb, 1977., 70.-75. Također je korišteno djelo: Obraćenje Židova Marije Alfonsa Ratisbonnea. Iz vjerodostojnih izvješća i vlastoručnih pisama: Alfonsa Ratisbonnea, baruna de Bussierra i Dufriche-Desgenettesa, utemeljitelja nadbratovštine m. G. od Pobjede, Sarajevo, 1897. (dalje: Obraćenje). Rijedak primjerak ovoga zadnjeg djela nalazi se u Središnjoj nadbiskupijskoj i fakultetskoj knjižnici u Đakovu.

${ }^{4}$ O tome više u: B. KALIN, Povijest filozofije, Zagreb, ${ }^{22}$ 1998., 200s.

${ }^{5}$ Conversione, 13.
} 
U drugoj fazi odnosa prema vjeri, Ratisbonne počinje prezirati sve što je kršćansko, osobito katoličko. Točka prekretnica dogodila se 1825 . godine. Te se godine, naime, njegov stariji brat Thèodore obratio na katoličanstvo i potom zaredio za svećenika isusovca te je isprva službovao u njihovom rodnom gradu, a potom je premješten $u$ Pariz. Bratovo obraćenje Alphonse vidi kao ludost pristanka na katolički fanatizam te je posve prekinuo odnose s bratom i obilno se hranio dubokom mržnjom prema Crkvi i svećenicima, osobito prema papi i isusovcima.

Da bismo došli do treće faze, moramo se vratiti Ratisbonneovu putovanju. Tu susreće mnoštvo zgoda koje mu produbljuju mržnju prema katoličanstvu. Tako u prvim danima putovanja, brod kojim je Ratisbonne putovao, prije dolaska u Napulj, zaustavlja se u Civitavecchiji. Čuvši crkvena zvona i saznavši da katolici slave Marijino bezgrešno začeće, Alphonse nije htio ni izaći s broda, jer bi tako stupio na tlo papinske države, pape na kojega nije mogao ni pomisliti, a da to ne bude $s$ prijezirom i mržnjom. Već je tu njegov dnevnik s putovanja počeo bivati ispunjen uvredama i ismijavanjem katoličkoga.

Međutim, na svom putovanju Ratisbonne ipak završava u Rimu. Kako je tamo došao, ako smo ustvrdili da nipošto nije htio pohoditi papinski grad, iako su ga neki prijatelji iz Napulja na to žarko poticali? Naizgled, u Rim je došao slučajno. Dok je u Napulju namjeravao kupiti kartu kako bi posjetio Palermo, krivo dolazi do ureda koji prodaje karte za Rim. Pod dojmom savjeta prijatelja, kako sam sebi tumači, ipak odlučuje poći za Rim. Tamo je stigao 6. siječnja 1842. (svetkovina Bogojavljenja), a plan je bio da se u Napulj vrati što prije, jer 20. siječnja mora ići dalje. No, ostat će puno duže.

Drugog dana boravka u Rimu slučajno susreće svoga školskog prijatelja, baruna Gustavea de Bussièresa, koji ga je ubrzo upoznao sa svojim bratom, opet imenom Thèodore. Ratisbonne je o njemu dotad samo čuo da je prešao s protestantizma na katoličanstvo, što je bilo dovoljno da mu bude antipatičan. Ipak, iz puke pristojnosti te budući da je Thèodore pisao o svojim putovanjima na Istok, Ratisbonne prihvaća Thèodoreov poziv da ga ugosti u svojoj kući.

Za vrijeme razgledavanja Rima u pratnji baruna Gustavea, koji ga bezuspješno pokušava obratiti na protestantizam, dva događaja opet u Ratisbonnea izazivaju dotad najveći bijes i najgore teške riječi protiv katoličanstva: ponajprije obilazak rimske židovske četvrti nazvane Ghetto i njegova zgroženost nad okrutnošću katolika spram Židova te saznanje da se u crkvi na Campidogliju priprema obred krštenja dvojice Židova.

$S$ druge strane, Ratisbonne je proživio i četiri događaja koja su ipak odavala njegovu, makar i nesvjesnu, propetost prema božanskome. Prvi je događaj iz perioda prije putovanja. O tome vremenu ovako piše: $\gg$ bijaše neka praznina u mome srcu i ne 
bijah sasvim sretan u obilju materijalnoga $\ll^{6}$. Izlaz iz toga stanja vidio je u predanju svojoj zaručnici s kojom je postao posebno zaokupljen i koju je jako volio. Zbog nje i očekivane buduće potpune sreće počinje se jednom spontano moliti Bogu, zahvaljujući na divnoj zaručnici u kojoj je dobio anđela svoga života. Drugi se događaj zbio na Novu godinu 1842. Tad je Ratisbonne bio u Napulju te osamljen i tjeskoban u ovom slavljeničkom danu, odluči - a da ni sam ne zna kako - potražiti mir u jednoj crkvi u kojoj se služila misa. Tu je doživio čudan osjećaj koji ga je nagnao da ipak na svoj način moli za svoju zaručnicu, strica, za pokojne roditelje, za sve drage kao i za nove poticaje kako pomoći Židovima koji su u potrebi. Nakon molitve više nije osjećao tjeskobu, nego je čuo nepoznat glas da mu je molitva uslišana. Treći je događaj jaka mučnina te uznemirenost i potresenost koju je osjetio zbog čudne moći koja se širila crkvom Svete Marije na rimskom Campidogliju, u koju je slučajno ušao i iz koje je morao izaći prije nego što su ga isti osjećaji posve savladali. Četvrti se događaj zbio također u Rimu, i to za vrijeme produženog boravka u Vječnome gradu. U noći s 19. na 20. siječnja 1842. Ratisbonne se naglo probudio i nasuprot sebe ugledao veliki crni križ bez korpusa koji se $s$ kraja puta približavao prema njemu. Nastojao je što prije zaspati i sutradan više nije mislio o tome što se dogodilo tu noć. Kasnije će shvatiti da je sve ovo bilo znak Božjega milosrđa i providnosti koja je pripravljala njegovo obraćenje.

Dva dana prije planiranog odlaska iz Rima Ratisbonne je posjetio kuću Thèodorea de Bussièresa. Iako je samo namjeravao ostaviti karticu pozdrava na odlasku, uobičajenu za ono vrijeme, ipak je osobno susreo Thèodorea i njegovu obitelj. Razgovor koji se poveo ubrzo je dotaknuo vjerodostojnost katoličanstva. Bila je to prilika da Ratisbonne pokaže što je sve čuo i pročitao protiv Crkve. U jednome je trenutku Thèodore stavio pred Ratisbonnea neobičan i za njega bizaran zahtjev, koji mu se ipak u konačnici učinio kao zgodna zabava i crtica s putovanja koju će kasnije ismijati. Radilo se o tome da Ratisbonne oko vrata nosi Čudotvornu Gospinu medaljicu, kojoj je Thèodore pridavao silnu važnost, te da ujutro i navečer izgovara molitvu Memorare sv. Bernarda iz Clairvauxa (12. st.), koju treba prepisati u svojoj sobi.7 Sam spomen sv. Bernarda izazivao je bijes u Ratisbonna, jer je njegov brat svećenik napisao životopis toga sveca. Ratisbonne odlučuje popustiti da

\footnotetext{
${ }^{6}$ Isto.

7 »Spomeni se, o predobrostiva Djevice Marijo, kako se još nikad nije čulo da si ti ikoga zapustila tko se tebi u zaštitu utekao, tvoju pomoć zatražio i tvoj zagovor zaprosio. Ovim pouzdanjem ohrabren utječem se i ja k tebi, Djevice djevica; k tebi, Majko dolazim; pred tobom kukavan grešnik stojim i uzdišem. Nemoj, Majko Vječne Riječi, prezreti mojih riječi, već ih čuj i milostivo usliši. Amen.« Riječ je o jednoj od najljepših marijanskih molitvi, koje i danas rado mole pobožni vjernici. Za nju se drži da onaj koji ju svakodnevno moli, unatoč svojim slabostima, neće biti izložen vječnom prokletstvu te će iskusiti velike milosti uslišanja.
} 
ne ispadne tvrdoglav te kako bi priveo kraju besmislenu raspravu s Thèodoreom $\mathrm{i}$ njegovom upornošću.

Thèodore i njegove dvije kćerke stavile su Ratisbonneu medaljicu oko vrata, a on je kasno navečer prepisao molitvu. Međutim, ne baš kratka molitva sutradan mu se stalno vraćala u misli. Prije odlaska otišao je do Thèodorea da mu vrati originalni ispis molitve te je odlučio, na Thèodoreovo inzistiranje i čudeći se sam sebi, ostati u Rimu do 22. siječnja. Thèodore je, naime, bio uvjeren da će Ratisbonneova dobrota prerasti u želju da postane katolikom, iako nije znao kako i kada, te je zamolio svoju djecu i bratovštinu kojoj je pripadao, osobito najboljeg prijatelja Augustea de La Ferronnaysa te isusovca o. Villeforta da mole na tu nakanu. Zbog posebnog nutarnjeg poticaja i sam je Thèodore počeo još gorljivije moliti na istu nakanu.

U jednoj od šetnji Rimom s Thèodoreom, 20. siječnja 1842. godine, Ratisbonne ulazi i u crkvu sant'Andrea delle Fratte. Tamo je Thèodore trebao dogovoriti detalje oko mise zadušnice za svoga iznenada preminulog prijatelja, spomenutog de La Ferronaysa. Ratisbonne nije znao da je taj čovjek molio za njegovo obraćenje te da je čak i svoju smrt prikazao na tu nakanu. Crkva u koju su ušli postat će ključno mjesto Ratisbonneova života, jer u njoj započinje treća faza njegova odnosa $s$ Bogom i Crkvom. Naime, upravo se tu prije 175 godina dogodilo čudesno i naglo Ratisbonneovo obraćenje posredstvom Gospina ukazanja.

Kako Ratisbonne opisuje ovaj događaj? Sjeća se da u crkvi, koja je i danas poznata po Berninijevim anđelima, nije vidio nikoga, osim jednog crnog psa koji ga je ometao u hodu. ${ }^{8} \mathrm{U}$ trenutku kad mu se pas izgubio iz vida, nestala je i sama crkva u kojoj je bio te je, osjetivši nutarnji nemir, vidio samo jedno - sjajnu bijelu boju iznad oltara sv. Mihaela kapele u koju je zašao, u čijem je središtu, u zraku, bila Presveta Djevica Marija, koja se pokazala u svoj svojoj ljepoti i okružena vijencem slave i sjaja, iz čijih se raširenih ruku, poput rijeke, razlijevala milost oproštenja i milosrđa. ${ }^{9}$ Iako

\footnotetext{
${ }^{8}$ Navodimo jedno od tumačenja spomenute pojave psa: »U prvome trenutku Alphonse ne razumije da u prisutnosti te životinje ima nešto neprirodno i da je sâm pas nešto čudno. Ubrzo će to shvatiti, jer pas, koji tijekom godina postaje sve manji i manji, ponovno će doći uznemiravati ga, njega i njegove najbliže. To je đavao.« A. BERNET, Skroviti život Katarine Labouré ili Čudesna povijest Čudotvorne medaljice, 252.

${ }^{9}$ Danas se u toj crkvi nalazi Ratisbonneova bista i ploča koja svjedoči o čudu obraćenja. Vrijedi istaknuti da u vrijeme čuda u spomenutoj crkvi nije bilo ni kipa ni slike Blažene Djevice Marije. Danas se u toj crkvi, na spomen čuda Ratisbonneova obraćenja, nalazi slika Gospe s Čudotvorne medaljice. Usp. Obraćenje, 44., 63. Oltar sv. Mihaela 18. siječnja 1848. posvećen je Gospi od Čudotvorne medaljice (pučki nazvanoj Gospi od Čuda), a ubrzo je postalo drago marijansko svetište poznato u cijelom svijetu. Zbog velike pobožnosti i mnogobrojnih obraćenja koja su se iz njeg rodila, papa Benedikt XV. ovo je svetište prozvao »Rimskim Lurdom «, a Pio XII. uzdigao je crkvu na rang bazilike. http://www.santandreadellefratte.it/index.php?option=com_content\&view=article\&id=12\&Itemid=139 (1. VI. 2017.).
} 
Gospa nije govorila, Ratisbonne je odjednom sve spoznao - kako težinu stanja u kojem se dotad nalazio, tako i rugobu grijeha, ali i ljepotu katoličke vjere. Shvatio je i da se naglo i posve promijenio. Thèodore se vratio za svega nekoliko minuta i našao je Ratisbonnea kako kleči u kapeli posvećenoj Anđelu čuvaru, uplakan i posve izvan sebe. Alphonse je žarko ljubio svoju medaljicu te je prepoznao da je žena koju je vidio izgledala točno onako kako je Gospa prikazana na medaljici. Što se potom dogodilo ovako opisuje Ratisbonne:

$\gg$ Moje su prve riječi bile riječi zahvalnosti za gospodina de La Ferronnaysa i za Nadbratovštinu Naše Gospe od Pobjede. Znao sam sa sigurnošću da je grof de La Ferronnays molio za mene, ali ne bih znao reći kako sam to saznao, kao što to ne mogu ni za istine u koje sam povjerovao i koje sam spoznao. Sve ono što mogu reći je da je u jednom trenutku s mojih očiju pala koprena; ne samo jedna koprena, nego mnoge koprene koje su me obavijale, a koje su potom nestale kao što snijeg, blato i led nestaju pod žarkim suncem. Izašao sam iz groba, iz tamnog ponora i postao živo biće, istinski živo, ali sam ipak plakao! Na dnu ponora vidjeh užasne bijede od kojih me izbavi djelo beskrajnog milosrđa: drhtao sam vidjevši sve svoje zloće i bijah zapanjen, ganut, slomljen zadivljenošću i zahvalnošću. Mislio sam na svoga brata s neizrecivom radošću, ali su se sa suzama ljubavi pomiješale suze sažaljenja. Jao, koliki ljudi mirno silaze u ovaj ponor očiju zatvorenih ohološću i ravnodušnošću ... silaze, bivaju živi progutani strašnim tminama ... i moja obitelj, moja zaručnica, moje sirote sestre! Oh, bolnog li nemira! Mislio sam na vas, na vas koje ljubim: na vas kojima sam darivao prve molitve... zašto ne podignete oči prema Spasitelju svijeta, čija je krv izbrisala istočni grijeh? Oh, mrlja ove ljage je užasna! Ona ostavlja posve neprepoznatljivo stvorenje koje je stvoreno na sliku Božju. Pitao sam se kako sam saznao za ove istine, budući da je sigurno kako nikad nisam otvorio ni jednu vjersku knjigu, kako nikad nisam pročitao ni jednu jedinu stranicu Biblije, a dogma o istočnom grijehu, u naše dane posve zaboravljena ili zanijekana u Židova, nikad nije ni na jedan jedini trenutak obuzela moje misli; čak dvojim da sam prije poznavao i njegovo ime. Kako sam, dakle, došao do te spoznaje? To ne znam reći. Znam samo da ulazeći u crkvu nisam znao ništa, a da sam izlazeći iz nje sve jasno vidio. (...) Vjerujem da ću reći istinu, ako ustvrdim da iako nisam imao nikakvo doslovno znanje, mogao sam tumačiti smisao i duh dogmi. Shvaćao sam ove stvarnosti više nego što sam ih vidio, i osjećao sam ih preko neizrecivih učinaka što su ih one izazvale u meni. Sve se događalo u meni i ti utisci, tisuće puta brže od misli, tisuće puta dublje od promišljanja, nisu samo dirnuli moju dušu, nego su me na neki način okrenule i upravile drukčijem smislu, prema drukčijem cilju i novom životu. (...) Božja ljubav tako je zauzela mjesto bilo kojoj drugoj ljubavi, pa se i moja zaručnica pojavila u drukčijem vidu. Ljubio 
sam je kao objekt koji Bog drži u svojim rukama, kao dragocjeni dar koji potiče na još veću ljubav prema darovatelju. ${ }^{10}$

Isprva je o svome iskustvu i radosti koja mu je obuzela život želio pričati isključivo sa svećenikom, pa ga je Thèodore odveo u crkvu Al Gesù, kod isusovca o. Villeforta. $\mathrm{Za}$ Ratisbonnea svijet više nije predstavljao ništa te su posve nestale predrasude spram Crkve. Zato je poželio biti monahom među trapistima, kako bi se posvetio samo vječnim stvarima te kako bi se očuvao od napada obitelji i prijatelja da je lud. Međutim, o. Villefort upućuje ga u to da istinski vjernik ne bježi od podsmjeha i krivih sudova svijeta, nego je spreman piti iz kaleža agonije, kako je Krist i navijestio svojim učenicima. Ratisbonne je ubrzo obavio duhovne vježbe te 31. siječnja 1842. u crkvi Al Gesù primio sakramente inicijacije koje mu je podijelio kardinal Patrizzi u prisutnosti svoga kuma Thèodorea de Bussièresa te mnogih okupljenih, njemu nepoznatih ljudi, u kojima je prepoznao očiti znak Božje prisutnosti. Kao krsno ime uzeo je ime Marija. U narednim je danima obavio još jedne duhovne vježbe te susreo papu Grgura XVI. u privatnoj audijenciji, kojega je doživio kao poniznog oca koji u svoj zagrljaj prima izgubljenog sina. Ovako svoj spis završava Ratisbonne:

»Zahvalnost! To će sada biti moj zakon i moj život! Ne mogu ju izreći riječima, pa ću gledati da je izrazim djelima... Pisma moje obitelji potpuno su mi vratila slobodu: tu slobodu posvećujem Bogu i prikazujem ju od sada, zajedno s cijelim svojim životom, za služenje Crkvi i mojoj braći, pod Marijinom zaštitom! ${ }^{11}$

Papa Grgur XVI. osnovao je posebnu komisiju koja je ispitala čudo Ratisbonneova obraćenja. Dana 3. lipnja 1842. proglašen je zaključak provedene istrage: »Temeljito je dokazano, da je naglo i potpuno obraćenje Alphonsea Marije Ratisbonnea sa židovstva na katoličku vjeru po zagovoru blažene Djevice pravo i golemo čudo, koje je sam predobri i svemogući Bog učinio. ${ }^{12}$

Ratisbonne se potom kratko nastanio u pariškom predgrađu Saint-Germain, upravo u sirotištu gdje je njegov brat Thèodore bio rektorom. Iz zahvalnosti tu je podigao kapelicu Bezgrešnog začeća. Osjetivši u sebi poziv na svećeništvo, stupa u isusovački red i postaje svećenikom. Kratko vrijeme djeluje kao duhovnik u jednome zatvoru, a potom odlazi u Jeruzalem. U međuvremenu njegov je brat osnovao kongregaciju Naše drage Gospe Sionske za obraćenje Židova. To je postala jedina Ratisbonneova želja te se pridružuje istoj kongregaciji i odlazi u Jeruzalem. Gradio je škole i zavode po Svetoj zemlji, pisao knjige te dušobrižnički djelovao u skladu sa

\footnotetext{
${ }^{10}$ Conversione, 45.-48.

${ }^{11}$ Isto, 53.

${ }^{12}$ Obraćenje, 63. Kurziv je naš, a citat je prilagođen hrvatskom standardnom jeziku.
} 
svojim poslanjem približavanja Židova katoličanstvu. U Jeruzalemu ustanovljuje i katolički institut sv. Petra, kasnije poznat kao »Ratisbonne centar «, isprva s poslanjem obraćenja Židova. ${ }^{13}$ Ratisbonne umire 6. svibnja 1884. godine u Ain Karimu na glasu svetosti.

\section{Neki teološki vidovi Ratisbonneova obraćenja}

\subsection{OzBILJNOST I VAŽNOST OBRAĆENJA}

Teološki govoriti o obraćenju (hebr. šûb, tešubah, grč. metánoia, lat. conversio) znači govoriti o promjeni životnog puta, što uvijek uključuje istinsku vjeru i poslušnost, pri kojoj se cijela čovjekova osoba odvraća od idolopoklonstva lažnim bogovima i približava Bogu živomu i istinskomu (usp. 1 Sol 1, 9). ${ }^{14}$ Puno je razloga koji mogu pokrenuti obraćenje, poput žudnje za istinom ili smislom, želje da se bude boljim i svetijim, straha od začaranosti svijeta i dr. Međutim, svako obraćenje podrazumijeva i mnoge nužne dinamizme kako bi postalo stvarno radikalna i korjenita promjena puta. Zato je obraćenje proces koji u sebi uključuje priznanje vlastite grešnosti, iskreno kajanje zbog učinjenog ili propuštenog, živu i osobnu vjeru u Isusa Krista kao Spasitelja, gorljivu želju za ispunjavanjem Božje volje te vršenjem njegove zapovijedi. ${ }^{15}$ To znači da se realno pristajanje na zahvaćenost milošću, ili njezino osobnije otkrivanje, mora 'utjeloviti' u stvarnostima koje čine mozaik obraćenja: u krštenju i pokori, u oproštenju grijeha, u primanju Duha i u prožetosti spasenjem. ${ }^{16}$ Drugim riječima, obraćenje je vjernost bez ako i ali u sveobuhvatnijem navikavanju starog života na novi put s Bogom. Taj novi put s Bogom zapravo je stari i jedini put za svakog čovjeka, ukoliko se obraćenjem vraća na izvorni put zajedništva Boga i

${ }^{13}$ Međutim, od II. vatikanskog koncila ovaj institut, kao i redovnici Kongregacije Gospe Sionske koji ga vode, bitno mijenjaju svoje poslanje. Institut postaje $\gg$ Centar hebrejskih studija za kršćane $\ll$ i kao takav se profilira u simbol kršćanskog zanimanja za židovstvo. Nakon turbulentnog razdoblja početkom XXI. stoljeća, u kojem je djelovanju centra spočitavan relativizam i reduciranje kršćanskoga na hebrejsko, danas centar djeluje kao Odsjek Papinskoga sveučilišta Salesiana u Rimu. Usp. P. S., Il caso Ratisbonne, u: Il Regno - Attualità, 14/2001., 448.; L. PR., Ratisbonne a Roma, u: Il Regno - Attualità, 4/2003., 93.; https://www.unisal.it/notizie/vita-allups/444-il-centro-studiratisbonne-di-gerusalemme-eretto-a-sezione-della-facolta-di-teologia-dellups (25. V. 2017.). O biblijsko-teološkim razlozima nepotrebitosti misija prema Židovima, ali i o potrebitosti svjedočenja Isusa Krista u židovskoj prisutnosti vidi više u: I. RAGUŽ, (Ne)potrebitost kršćanskih misija spram židovstva i islama, u: ISTI, Teološki fragmenti I., Đakovo, 2016., 460.-470., osobito 461.-467.

${ }^{14}$ Biblijsko-teološki presjek fenomenologije obraćenja vidi u: P. GIANNONI, Conversione, u: G. BARBAGLIO, G. BOF, S. DIANICH (ur.), Teologia, Cinisello Balsamo, 22003., 292.-303.

${ }^{15}$ Usp. T. Z. TENŠEK, Obraćenje, u: L. PACOMIO, V. MANCUSO (ur.), Enciklopedijski teološki rječnik, Zagreb, 2009., 753.-755., ovdje 753.

${ }^{16}$ Usp. E. ZEMGER, Obraćenje, u: A. GRABNER-HAIDER (ur.), Praktični biblijski leksikon, Zagreb, 1997., 252.-254., ovdje 253. 
čovjeka, stvorenog i spašenog u Kristu. Kršćanina katolika stoga bi se jednostavno moglo odrediti kao čovjeka koji se obratio Bogu po objavi Isusa Krista.

Iz rečenoga postaje vidljivo da je subjekt obraćenja konkretna ljudska osoba, a sadržaj osoba Isusa Krista. ${ }^{17}$ Jedino je ljudska osoba obdarena sposobnošću da se slobodno primakne i svojevoljno opredijeli za Krista, što znači da odluči svu cjelovitost svoga bića - svoje središte i sve dimenzije svoga života - navikavati na njega, na njegovo evanđelje i zapovijedi. Obraćenje i poslušna vjera temeljni su ljudski činovi kojima on odgovara na evanđelje. ${ }^{18}$ Obratiti se zato, nadalje, znači vjerovati evanđelju koje je Kristovo, ali i vjerovati da je samo obraćenje Kristov dar, jer nitko ne dolazi Ocu osim po njemu (usp. Iv 14, 6).

Na putu obraćenja čovjek nikad nije sam i nikad nije gotov. Obraćenje je uvijek povezano s onima koji su već na tome putu, dakle s Crkvom - kršćanskim bratstvom i prostorom spasenja na zemlji. Isto tako, obraćenjem, iako je ono u svome temelju naglo i potpuno, čovjek ne može dostići točku u kojoj bi svoje obraćenje mogao proglasiti dovršenim i zaokruženim. Obraćenje je zapravo čovjekovo navikavanje na Božju ozbiljnost u vlastitom životu. To znači da je uvijek aktualno i potrebno je stalnosti i ponavljanja, odnosno strpljivog i polaganog proširivanja na sve vidove čovjekova života i njegove svakodnevnice. Možemo to izreći i ovako: obraćenje je vjernost promjeni koja je omogućila tu istu vjernost i po kojoj se čovjek otvorio daru spasenja. Ne čudi, stoga, što je sadržaj prve rečenice o kraljevstvu Božjem upravo obraćenje: »Ispunilo se vrijeme, približilo se kraljevstvo Božje! Obratite se i vjerujte evanđelju! $(M k 1,15)$. Zato, kako piše teolog Ratzinger,

»ne spašava jednostavno povratak samome sebi, nego, štoviše, odvraćanje od sebe i obraćanje Bogu koji poziva. Čovjek nije upućen na zadnju dubinu svoga 'ja', nego na Boga koji mu pristupa izvana, na Ti, koje prodire u nju i tako ga oslobađa. Stoga metanoia ima isto značenje kao i poslušnost i vjera; zato ona stoji u sklopu zbiljnosti Saveza; zato je ona upućena na zajednicu onih koji su pozvani na isti put: ondje gdje se vjeruje u osobnoga Boga, gdje horizontalnost i vertikalnost, nutarnjost i služenje više nisu krajnja proturječja. To još jednom jasno pokazuje da metanoia nije bilo kakav kršćanski stav, nego temeljni kršćanski čin uopće, shvaćen, dakako, s jednoga posve određenog vidika: vidika promjene, preokreta, prijelaza u novo i drugačije biće. Da bi postao kršćanin, čovjek se mora promijeniti, ne samo u nekom pogledu, nego bez pridržaja, sve do krajnje dubine svoga bića. $\ll{ }^{19}$

\footnotetext{
${ }^{17}$ Usp. T.Z. TENŠEK, Obraćenje, 753.

${ }^{18}$ Usp. E. ZEMGER, Obraćenje, 253.

${ }^{19} \mathrm{~J}$. RATZINGER, Teološki nauk o principima, 68.
} 
Slojevitost i dinamičnost obraćenja ukazuje nam da bismo ovim pojmom opravdano trebali imenovati sve zaokrete $\mathrm{k}$ Bogu i promjene $\mathrm{u}$ duhovnom životu. ${ }^{20}$ Ovdje ćemo izdvojiti samo tri koji nam se čine najčešćima. Prvo, obraćenje označava prijelaz iz stanja grijeha u prijateljstvo s Bogom po sakramentima krštenja i ispovijedi. Drugo, ono označava i produbljivanje vlastite vjere, odnosno prijelaz iz vjere koja se živjela bez pripadanja, tradicionalno i površno u osobnu vjeru u Boga Isusa Krista koja dovodi i do tješnje pripadnosti Crkvi. I kao treće, obraćenje označava iznenadni trenutak čovjekova susreta s nebom, do kojeg su dovele razne osobe i okolnosti, a kojemu znamo dan i trenutak te nakon kojeg osoba počinje živjeti na radikalno drukčijem putu, posve nezamislivom za period prije obraćenja. Za obraćenoga je, dakle, taj put bitno nov, budući da na njega dolazi rezom s ranije izabranim pogrešnim smjerovima, mentalitetom i horizontima po kojima je rasuđivao ljudsko i božansko. Upravo po toj promjeni puta obraćenik na posve nov i drukčiji način vidi sebe u svjetlu Božje istine o čovjeku koji je stvoren i pomilovan milošću, ali koji je u svojoj slobodi u svijet unio grijeh i grešnost. Iako nagla obraćenja podrazumijevaju daljnje korake, važno je istaknuti da takva obraćenja znaju biti i potpuna obraćenja. To znači da se u obraćenoga sve iznenada i odjednom naviklo na Božju ozbiljnost. Model takvog obraćenja zasigurno je ono Pavlovo pred Damaskom, potaknuto iznenadnom objavom Isusa Krista koja u trenutku radikalno i potpuno mijenja njegov život (usp. Dj 9, 1-19; 22, 3-21). Ovo Pavlovo obraćenje, poput paradigme, predstavlja početak iznenadnih plodova novosti Kristove milosti koja korjenito mijenja živote onih koji ne vjeruju.

\section{2. 'SKOK VJERE'}

Ratisbonneovo obraćenje može biti promatrano s mnogih točki gledišta. Tako se, na primjer, u njemu može vidjeti jedan od načina isticanja rimskog odnosno papinskog autoriteta, dobrodošlog za ono vrijeme. Naime, padom Napoleona 1815. godine stvorena je prilika za obnovu i bolju centralizaciju papinskog autoriteta na civilnom području. Također, u to se vrijeme obnavlja pučka pobožnost i srednjovjekovna teologija te novo proljeće misijskog djelovanja Crkve, pa se Ratisbonneovo obraćenje može čitati kao poseban izričaj navedenoga. Međutim, obraćenje je prije svega i ponajviše teološki događaj. Zato držimo da Ratisbonneovu obraćenju u

\footnotetext{
${ }^{20}$ Kardinal Martini razlikuje četiri lica obraćenja koja mogu opisati kršćanski itinerariji: vjersko obraćenje (osoba donosi odluku da bude potpuno Božja, poput sv. Augustina), moralno obraćenje (osoba odlučuje živjeti prema nauku Crkve, poput Ignacija Loyolskog), intelektualno obraćenje (osoba intelektualnim naporom spoznaje vjerodostojnost Crkve, poput Henryja Newmana) i mistično obraćenje (osoba kontemplira Boga prisutnog u svijetu te svijet razmatra u Bogu, poput Terezije Avilske). Usp. C. M. MARTINI, Il giardino interiore. Una via per credenti e non credenti, Milano, 2014., 143.-150.
} 
cjelini treba pristupiti teološki, kako bi se izbjegle površnosti i redukcije koje nose gore navedeni i njima slični pristupi. Zapazili smo da ni sam Alphonse ne zna posve jasno opisati što mu se dogodilo. Zato u njegovom novom životu treba prepoznati 'gramatiku' onoga što mu se istinski dogodilo. Stoga ćemo ukazati na tri vida koji teološkom hermeneutikom proizlaze iz Ratisbonneova obraćenja, a koji su vrlo važni za našu teologiju, vjeru i duhovnost, budući da nas podsjećaju na istinsku fizionomiju duhovnog i egzistencijalnog obraćenja, koje se bitno razlikuje od pukog konvertiranja, odnosno preobraćenja na neku drugu konfesiju, koje često nije ni duhovno ni egzistencijalno.

Prvo, naglo i potpuno obraćenje Bogu je stvarno moguće. Iako, da tako kažemo, redovita obraćenja nisu nagla i iznenadna te im teško možemo odrediti dan, mjesto i vrijeme, postoje milosni trenutci u kojima Bog dopušta nagle prevrate ne samo smisla i razmišljanja, nego cjelokupnog ljudskog života. S ovog gledišta približili smo se pravoj biti obraćenja - ono je promjena života, ono je stupanje novog stvorenja u novom životu koji pogađa čitavu njegovu egzistenciju. $S$ ovog gledišta spoznajemo i da se $\gg$ Bog ne umara pružati ruku $\ll^{21}$ da se obraćenje dogodi, pa i onda kad to znači zahvat Božje providnosti kroz otajstveno djelovanje u svijetu kako bi se obratili i oni za koje se to čini potpuno nemogućim. Zato nema trenutka koji za čovjeka ne bi bio povoljan da se promijeni život. Čovjek se, dakle, može promijeniti unatoč svojoj naravi. Milost, doduše, pretpostavlja narav, ali je ona jača od naravi te ju zato usavršava i uzdiže. Zato ono što je ljudima nemoguće, Bogu je moguće (usp. Mt 19,26). Iako se čini da čovjek izvana raste u mržnji spram vjere, on iznutra biva ojačan i potican na obraćenje koje je uvijek ponajprije djelo Duha Božjega. ${ }^{22}$

Drugim riječima, ne postoji vrijeme u kojem čovjek, ma koliko bio uronjen u svoju nevjeru i stavove te se čini da biti katolikom nikako ne može biti njegovim temeljnim opredjeljenjem, nema priliku suočiti se s milošću koja je uvijek prisutna u svakom čovjeku i koja u njemu stvara i potiče obraćenje koje on mora u svojoj slobodi prihvatiti kao istinski i bezuvjetno svoje novo stvaranje. U tom kontekstu, i mržnju prema Crkvi vidimo kao stvarnost koja može skrivati duboko slutnju o privlačnosti Crkve kao 'stupa i uporišta istine' (usp. 1 Tim 3, 15). Čovjek je bogotražitelj, u njega je upisana naravna potraga za Stvoriteljem i u njemu je djelatna milost zbog koje čezne za Spasiteljem i za slobodnim prihvaćanjem dara spasenja. Upravo je Ratisbonneovo obraćenje izričit znak svega rečenoga. Nakon niza naizgled slučajnosti u svome životu, Ratisbonne će napokon shvatiti:

${ }^{21}$ FRANJO, Misericordiae vultus. Bula najave Izvanrednog jubileja milosrda, Zagreb, 2015., br. 19.

22 »Nakon Vazma Duh je Sveti onaj koji 'dokazuje svijetu što je grijeh' (Iv 16, 8-9), odnosno to što je svijet nije povjerovao u onoga koga je Otac poslao. Ali taj isti Duh, koji otkriva grijeh, jest Branitelj koji čovjekovu srcu daje milost kajanja i obraćenja.« Katekizam Katoličke Crkve, Zagreb, 2016., br. 1433. 
>O božansko upravljanje! Postoji, dakle, otajstveni impuls koji prati čovjeka na putu života! Po rođenju sam primio ime Tobija, zajedno s Alpfonse. Zaboravio sam svoje prvo ime, ali to nije zaboravio nevidljivi anđeo. Bijaše mi on istinski prijatelj kojeg mi je nebo poslalo, a kojega nisam poznavao. Ajme! Postoji toliko Tobija na svijetu koji nikako ne poznaju ovoga nebeskog vodiča i koji se opiru njegovu glasu! $\ll^{23}$

Drugo, obraćenje se i ovdje potvrđuje kao kristološki događaj, jer vodi dubljem pritjelovljenju Kristu, a to znači i njegovoj Crkvi. Za sv. Pavla obraćenje ne predstavlja ponajprije promjenu ljestvice vrijednosti, nego prianjanje osobi Isusa Krista: $\gg$ Štoviše, čak sve gubitkom smatram zbog onoga najizvrsnijeg, zbog spoznanja Isusa Krista, Gospodina mojega, radi kojega sve izgubih i otpadom smatram: da Krista steknem i u njemu se nađem « $\left(\right.$ Ef 3, 8) ${ }^{24}$ Pavlov izričaj o stjecanju Krista i bivanju u Kristu uključuje pritjelovljenje i bivanje u njegovu Tijelu koje je Crkva (usp. Kol $1,18)$. Obraćenje nije stoga samo promjena neke točke života, poput smisla ili razmišljanja, nije ni samo kajanje ili pokora. Ono je sve to ako je novi život korjenito promijenjen život zbog osobe Isusa Krista koja pogađa čitavu ljudsku egzistenciju i kao takvo predstavlja uvjet da bi nastalo spasenje, da se iz ovoga dara i zahtjeva stvore kršćani i oblikuju sveci. ${ }^{25}$

Istu teološku logiku možemo iščitati iz Ratisbonneove zadivljenosti novošću osobe Isusa Krista koju je spoznao po Gospinu ukazanju i kojoj je otada uvijek ostao vjeran. Ratisbonneovo viđenje potpuno ga je uvuklo u istinu koju dotad nije poznavao. On spoznaje duh središnjih istina katoličke vjere o spasenju po Kristu, osjeća Kristov poziv za svećeništvo te cijeli svoj život gorljivo djeluje iz jezgre svoga novog temeljnog opredjeljenja. Njegov »skok vjere $\ll^{26}$ tu je posve sličan obraćenju sv. Pavla.

Ratisbonne se nakon događaja u crkvi i posjeta o. Villefortu uputio u bazilike sv. Marije Velike i sv. Petra kako bi zahvalio za primljenu milost i posvjedočio veliku ljubav prema Isusu Kristu:

»Proniknut živom vjerom u veliko otajstvo ljubavi Isusove u Presvetom Sakramentu, nije smio stupiti blizu oltara, gdje se čuva presveto tijelo Isusovo. Misao

\footnotetext{
${ }^{23}$ Conversione, 35 .

${ }^{24}$ To isto naglašava i Pieper: $\gg(\ldots)$ ono odlučujuće vjere nikada nije u objektivnim sadržajima u koje se vjeruje. Naime, vjernik, gdje god ga susreli, prvotno nema posla s objektivnim sadržajima, nego s Nekim. Taj Netko, svjedok, jamac jest 'glavna stvar', jer se bez njegova svjedočanstva uopće ne bi vjerovalo u objektivni sadržaj. No upravo to tvori bitnu razliku između religiozne vjere i svake druge vjere: taj Netko, na temelju čijeg svjedočanstva onaj koji vjeruje u religioznom smislu neki objektivni sadržaj prihvaća kao istinit i stvaran, jest sam Bog.«J. PIEPER, O vjeri. Filozofska rasprava, Zagreb, 50.

${ }^{25}$ Usp. J. RATZINGER, Teološki nauk o principima, 65., 74.-76.

${ }^{26}$ Usp. J. RATZINGER, Uvod u kršćanstvo. Predavanja o apostolskom vjerovanju, Zagreb, ${ }^{5} 2002 ., 23 \mathrm{~s}$.
} 
da je ondje naš Isus pod prilikom kruha bitno, stvarno i istinito prisutan ispunjala ga je svetim strahom, poštovanjem i poniznošću, te se ne usuđuje ni približiti Isusu, budući da je njegova duša još okaljana istočnim grijehom, nego ostaje kod vrata, tu ponizno kleči i sa strahopoštovanjem se klanja u prahu ondje skrivenome Bogu. (...) Osjećao se naš gorljivi obraćenik i u domu Gospodnjem tako blaženim, te nije bio kadar da izrekne u kakvoj mu je milini duša plivala. 'Oj, dobro je ovdje biti!' kliknuo bi pun svetog zanosa. 'Koliko su sretni i blaženi katolici kada pohode svoje crkve i koliko ih žarko moraju ljubiti! Kakva im revnost mora ražarivati srce, kako bi što bolje uresili i nakitili te domove Božje! Kako bi silno čovjek želio da čitav svoj život provede na ovom blagoslovljenom mjestu! Ovdje nije više zemlja, nego je nebo!' « ${ }^{27}$

Ovo svjedočanstvo ljubavi prema Kristu istodobno je i svjedočanstvo ljubavi prema njegovoj Crkvi, u kojoj je i po kojoj je Krist prisutan u svijetu. Ratisbonneov slučaj potvrđuje nam da nema obraćenja bez Crkve, ali i da nema obraćenja bez plodova za Crkvu. Otkriva se to u mnoštvu detalja - od Ratisbonneovih pobožnih pohoda rimskim bazilikama nakon viđenja, od želje da očituje odanost papi i primi sakramente inicijacije, kao i u već više puta spomenutom posvećenju života svećeništvu, redovništvu i misijskom djelovanju.

Treće, obraćenje je uvijek povezano s misionarima milosrđa ${ }^{28}$. Tim pojmom mislimo na sve one osobe koje su, u svome dubokom vjerskom iskustvu i zrelosti svoje osobne vjere, spasenjski suradnici obraćenja drugih u molitvi i nadi da se Božja sveopća spasenjska volja i ostvari. Drugim riječima, to su oni vjernici koji se ne zadovoljavaju izlikom da je Crkva ionako malo stado te da teško može rasti po čudesnim i iznimnim događajima. To su oni koji vjeruju da su obdareni mogućnošću da budu posrednici doticaja veličine Božjega praštajućega milosrđa i čovjekove grešnosti. Svojom suradnjom s milošću u obraćenju drugih oni se bore protiv ravnodušnosti za spasenje svih ljudi i osobito se posvećuju grešnicima. To znači da se bore i protiv dvoličnosti i sebičnosti vjere u koje bi se zatvorila svaka osobna vjera koja nije tu, zajedno s ljubavlju i nadom, i za druge.

Model misionara milosrđa izriče se u osobi Ratisbonneova 'slučajnog' pratitelja Thèodorea de Bussièresa, također obraćenika. On se ne da pokolebati Ratisbonneovom grešnošću, ne želi suditi i na cinizam uzvratiti cinizmom. Naprotiv, on prepoznaje dobro u Ratisbonneu i pozoran je prema nutarnjim poticajima, koji ga navo-

\footnotetext{
${ }^{27}$ Obraćenje, 42.-43. Citat je prilagođen hrvatskom standardnom jeziku.

${ }^{28}$ Ovdje analogijski koristimo izraz koji se rado koristio u Izvanrednom jubileju milosrđa i to za svećenike koji su imali poseban papinski mandat da budu »znak majčinske brižnosti Crkve prema Božjem narodu, omogućujući mu da duboko uđe u bogatstvo toga otajstva, tako bitnoga za vjeru.« FRANJO, Misericordiae vultus, br. 18.
} 
de da Ratisbonneovo obraćenje povjeri kao nakanu široj zajednici vjernika, svojih prijatelja. Slušajući iste poticaje, misionar milosrđa, često i sam obraćenik, zna kad je trenutak za upornost, a kad za šutnju, kad je trenutak da se drugome pusti da govori, a kad je trenutak za profinjenost. Misionari milosrda ne idu protiv slobode drugoga, oni ništa ne nameću niti dokazuju. Samo surađuju s milošću, duboko uronjeni u iskustvo vlastite vjere u Boga i čvrsto povezani u zajedništvo Crkve, znajući da se obraćenje događa po milosti susreta s Bogom. ${ }^{29}$

Osim Thèodorea, kojeg Ratisbonne naziva $\gg$ Marijinim anđelom $\ll^{30}$, tu je i svećenik isusovac o. Villefort, o kojem piše: »Ovaj Božji čovjek nije običan čovjek: on je srce, on je poosobljenje nebeske ljubavi $\ll$ te nastavlja opis događaja za vrijeme duhovnih vježbi prije svoga krštenja: »Međutim, tek što sam otvorio oči, oko sebe sam otkrio toliko drugih sličnih ljudi, za koje svijet sumnja čak i da postoje. Bože moj, kolika dobrota, pažnja i milost u srcima ovih istinskih kršćana. $\ll^{31}$ Ovdje treba spomenuti i Alphonseova brat Thèodorea, koji nije prestajao moliti za bratovo obraćenje.

Horizont misionara milosrđa otvara nam vidik i prema spasenjskoj suradnji Blažene Djevice Marije, koja se potvrdila i u Ratisbonneovu viđenju. Marija, dušom i tijelom uznesena u nebesku slavu, ne prestaje biti posebna, nebeska misionarka milosrda u svijetu, odnosno ne prestaje biti znakom i sredstvom istine povijesti spasenja, koja nam objavljuje da Bog djeluje u povijesti, ali tako da ljudima dolazi upravo preko samih ljudi. Vrhunac je te istine utjelovljenje Sina Božjega, u kojem jedna ljudska osoba - Marija iz Nazareta - omogućuje da Bog postane čovjekom i tako se spasenjski sjedini sa svim ljudima. Zato je ona pred Ratisbonneovim preobraženjem i pred svakim drugim obraćenjem, na jedinstven, majčinski znak Boga koji je uvijek blizu i koji djeluje u povijesti, koji djeluje u Crkvi, božanskoj ustanovi misionara milosrđa kojima je cilj spasenje duša. ${ }^{32}$ Ona je ljudsko lice u kojem se

${ }^{29}$ Ukoliko se obraćenje vidi samo kao promjena sustava vrijednosti, obraćenik lako upadne u zamku da svoj život stavi kao princip i mjerilo po kojem sudi druge. Tada umjesto vjernosti prema Isusu Kristu i zadivljenosti njegovom osobom zauzima zadivljenost samim sobom i spontano uvjerenje da je vlastito obraćenje Božja nagrada vlastitim zaslugama. Iz toga proizlazi stav dociranja drugima kako valja misliti, moliti, govoriti i raditi. Tvrdoglavo nepopustljivi takvi obraćenici ostaju sami ili izolirani s malom skupinom istomišljenika, koji se klanjaju vlastitoj slici Boga. O tome vidi više u: I. KORDIĆ, Kako razumjeti Međugorje, Međugorje - Zagreb, 2012., 90s.

${ }^{30}$ Conversione, 50.

${ }^{31}$ Isto, 49.

${ }^{32}$ Povijesno-spasenjsku istinu da Bog u povijesti i za spasenje ljudskog roda djeluje po Blaženoj Djevici Mariji i svim ljudima osobito prikladno ujedinjuje pokret Vojska Bezgrešne. O tom pokretu što ga je utemeljio sv. Maksimilijan Marija Kolbe na temelju nadahnuća na Ratisbonneovu obraćenju vidi više na: http://www.vojska-bezgresne.com (2. VI. 2017.). 
prepoznaje Božja vjernost Savezu, njegova gostoljubivost prema svakom čovjeku. Njezina prisutnost, kako ona prije 175 godina u Rimu, tako i njezina otajstvena prisutnost u životu Crkve, stvara obiteljsko ozračje prihvaćenosti, voljenosti, nježnosti i suosjećanja te brige osobito za one kojima je potrebno obraćenje i oproštenje kako bi povratili sličnost s Bogom (usp. Post 1,26). Možemo reći da se po Mariji Bog u ljudskoj osobi objavljuje i potvrđuje u svojim majčinskim božanskim atributima. Zato se u nadnaravnim događajima ukazanja najčešće pojavljuje Gospa kao posrednica mnogobrojnih milosti za svijet te kao ona koja poziva na obraćenje. Da, upravo nužnost obraćenja, za koja smo utvrdili da su moguća i nužna, da dovode do pritjelovljenja Kristu i Crkvi i da računaju na spasenjski doprinos mnogih, čini težište mnogih Gospinih ukazanja. ${ }^{33}$

\section{Umjesto zaključka: Vojska posrednika}

Povijesno-spasenjsku istinu da Bog u povijesti i za spasenje ljudskog roda djeluje po Blaženoj Djevici Mariji i svim ljudima osobito prikladno ujedinjuje pokret Vojska Bezgrešne. Ovaj je pokret osnovao sv. Maksimilijan Marija Kolbe (1894. - 1941.), a utemeljenje je u uskoj vezi s Ratisbonneovim obraćenjem. ${ }^{34}$ Naime, Maksimilijan kao mladi klerik iz Poljske, nastanjen u kolegiju franjevaca konventualaca, upravo je 20. siječnja 1917. godine, dakle 75 godina nakon Gospina ukazanja Ratisbonneu, donio odluku o osnivanju pokreta. Nadahnut na naglom Ratisbonneovu obraćenju posredstvom Čudotvorne medaljice, koje ga je učvrstilo u uvjerenju da povjerenje u Bezgrešnu može dovesti i do ostvarivanja onoga što se čini nemogućim, pokret zamišlja kao Gospino djelo za obraćenje grešnika, osobito masona. Dana 16. listopada 1917. osniva udruženje Militia Immaculatae - Vojska Bezgrešne. Kolbe je rado posjećivao svetište Gospe od Čudotvorne medaljice, a na oltaru ukazanja slavio je 29. travnja 1918. svoju mladu misu, s nakanom za obraćenje šizmatika, nekatolika i masona. Spomenuti pokret istu će medaljicu, sve do danas, širiti svijetom kao sredstvo obraćenja i posvećenja. ${ }^{35} \mathrm{~S}$ Čudotvornom medaljicom kao znakom raspoznavanja, cilj je pokreta, kako ga je odredio sam Kolbe, »globalno viđenje katoličkoga života u novome obliku, koji se sastoji od povezanosti s Bezgrešnom, našom svekolikom Posrednicom kod Isusa $\ll^{36}$. S tog gledišta, svaki je član Crkve na neki način već član Vojske Bezgrešne, budući da je posrednik spasenja za druge.

${ }^{33}$ Vidi više u: S. DE FIORES, Apparizioni, u: ISTI, Maria. Nuovissimo dizionario, I, Bologna, 2008., 21.-69., ovdje 55.-56.

${ }^{34}$ Opširnije u: Y. IVONIDES, Maksimilijan Kolbe. Čovjek koji je nadvladao smrt, Zagreb, ${ }^{2} 2008$.

${ }^{35}$ Usp. http://www.santandreadellefratte.it/index.php?option=com_content\&view=article\&id=12 \&Itemid=139 (1. VI. 2017.).

${ }^{36} \mathrm{http}$ ://www.vojska-bezgresne.com/vojska-bezgresne-videnje-katolickoga-zivota-u-novome-obliku (5. VI. 2017.). Kurziv je naš. 
Iako je glavni cilj ovoga pokreta bio opiranje širenju bezbožnosti i neprijateljstva prema Crkvi, jako je važno uočiti da ideja posredništva - odnosno biti »poslušna sredstva $\ll^{37}-\mathrm{u}$ obraćenju i posvećenju čini samu njegovu jezgru. Stoga ćemo ovaj rad zaključiti promišljanjem Karla Rahnera o ljudskom posredništvu u spasenju:

$\gg$ Ako želimo shvatiti u kojem se zapravo smislu preblažena Djevica, unatoč jedinom posredništvu Isusa Krista našega Gospodina, može nazvati našom Posrednicom, onda je dobro da ponajprije usmjerimo svoj pogled na činjenicu da mi, (... ) i u našem spasenju svi pripadamo skupa, te i tu, dakle, gdje valja nositi zadnju odgovornost, preteško breme milosti i neposrednost prema Bogu, našem spasu i sudu, svaki još treba da nosi ozbiljno i blaženo breme drugoga. Roditelji opominju djecu, brinu se za njihov spas i mole za njih; učitelji Crkve navješćuju istinu vjere; svećenici dijele Božje sakramente; svi molimo jedni za druge; svi mi skupa ispaštamo i nosimo teret krivice sviju, onako, kako smo i sami doprinijeli svoj dio toj ljudskoj krivnji. I u povijesti spasenja pripadamo zajedno, mi smo, kako Pavao jednom reče, Božji suradnici; svaki je na neki način - kako da reknemo drukčije? - također posrednik spasenja drugome. Ne u tom smislu, kao da je bio uzašao da donese spasenje vječnoga Boga. To spasenje po vlastitoj Božjoj milosti i djelu već je moralo biti kod nas, da bi ga jedan drugome mogao dati. Ne u tom smislu, kao da ga mi zapravo stvaramo; no budući da je ono tu, da je u Isusu Kristu došlo k nama, tj. u jedinstvenu ljudsku zajednicu u kojoj svako ovisi o svakome, htio je Bog u svojoj milosti i svome milosrđu da također jedan drugome budemo pomoćnici i u postizanju, u pružanju spasenja, što ga je Bog u Isusu Kristu tako položio već u ovo ljudsko zajedništvo povijesti, spasenja i propasti, da ono u tom zajedništvu zahvaća jednoga preko drugoga, premda je ono, gledano s Božje strane, u Isusu Kristu, glavi jednog čovječanstva, neposredno namijenjeno svakom jednako. Mi svi, nismo uzročnici spasenja, nismo oni koji dosad nepostojeće spasenje stvaraju da bi ono postojalo, nego smo samo razdjelitelji, i u tom smislu posrednici spasenja jedni drugima, te ćemo o tome čak morati položiti račun na Božjem sudištu, jesmo li u svojim mogućnostima, svojim životnim okolnostima i s danim nam darovima i talentima učinili za druge ono, što smo za one, koji su oko nas, posrednički trebali da učinimo. (... ) Svi su svima posrednici, baš jer je pojedinac od Boga ljubljen ukoliko uza se ima nepregledno mnoštvo braće i sestara u otkupljenju, te je s njima povezan u zajedništvu svetih. Svi su svima posrednici. Mi svima i svi nama! Tko drukčije misli, taj stvara od Božjeg kraljevstva, od zajedništva svetih, od Crkve vječnosti, od kraljevstva ljubavi - znao on to ili ne - puku zbirku pojedinačnih pojedinaca koji konačno, u spasenju, nemaju ništa jedni s drugima. ${ }^{38}$

\footnotetext{
${ }^{37}$ Isto.

${ }^{38}$ K. RAHNER, Marija, majka Gospodinova. Teološka razmatranja, Zagreb, 1980., 66.-68.
} 


\title{
RATISBONNE'S CONVERSION THROUGH THE MIRACULOUS MEDAL
}

\author{
Boris VULIĆ*
}

Summary: The concessions that are made in conversion have led to the scattering of the whole of conversion and the twilight of the core of conversion as a radical, sometimes sudden event in human life because of the novelty of Jesus Christ. For this reason, conversions are often inconsistent, superficial and neglected. The article aims to point out the radicality and necessity of conversion by presenting the conversion of the Jew Alphonse Ratisbonne to Catholicism, that occurred in 1842 in Rome. This amazing transformation is the greatest conversion through the Miraculous Medal, which is still insufficiently illuminated in our ambience. The second part brings some theological aspects that are always present in the dynamisms of every true conversion. It becomes clear that sudden conversions are possible, that they are intrinsically Christological events which bring fruits for the life of the Church, and which also involve the »missionaries of mercy《mediators that God puts on the path of conversion of individuals. The first among them is the Blessed Virgin Mary. This is uniquely summarized in the movement the $\gg$ Militia of the Immaculata «, at the same time describing the gift and task of every baptized person.

Keywords: Alphonse Maria Ratisbonne, Blessed Virgin Mary, Miraculous Medal, conversion, Catholicism, intermediation.

\footnotetext{
* Asst. Prof. Boris Vulić, Ph. D., Catholic Faculty of Theology, J. J. Strossmayer University of Osijek, P. Preradovića 17, 31400 Đakovo, Croatia, vulic@me.com
} 